\title{
Microbiological evaluation of peracetic acid for disinfection of acrylic resins
}

\section{Avaliação microbiológica de ácido peracético na desinfecção de resinas acrílicas}

\section{Abstract}

Purpose: The aim of this study was to assess the efficacy of peracetic acid (PAA) for the disinfection of dental acrylic resins experimentally contaminated with Candida albicans, Escherichia coli, Staphylococcus aureus and Pseudomonas aeruginosa.

Methods: Fifteen materials were used for each type of resin (thermosetting, self-curing and microwave-curing). Each material was placed in a test tube containing culture medium with a suspension of each microorganism and then incubated. The materials were rinsed and transferred to other tubes containing $50 \mathrm{~mL}$ of water for $5 \mathrm{~min}, 0.2 \%$ peracetic acid for $5 \mathrm{~min}$ or glutaraldehyde for $30 \mathrm{~min}$. The materials were placed in the culture agar and incubated. Microbial growth was determined by colony counting after plating.

Results: Candida albicans growth was inhibited by peracetic acid and glutaraldehyde treatments. The number of colonies on resins treated with saline was greater than $10^{5} \mathrm{CFU} / \mathrm{mL}$. In resins infected with E. coli, S. aureus and P. aeruginosa the colony growth was not inhibited by saline and peracetic acid, but it was totally inhibited by glutaraldehyde.

Conclusion: Surface disinfection using peracetic acid effectively inhibited C. albicans growth on all acrylic resins.

Key words: Peracetic acid; acrylic resins; Candida albicans

\section{Resumo}

Objetivo: O objetivo deste estudo foi avaliar a eficácia do ácido peracético (PAA) na desinfecção de resinas acrílicas dentais experimentalmente contaminadas com Candida albicans, Escherichia coli, Staphylococcus aureus e Pseudomonas aeruginosa.

Metodologia: Quinze corpos de prova (CP) foram utilizados para cada tipo de resina (termopolimerizáveis, autopolimerizáveis e ativados por energia de micro-ondas). Cada CP foi colocado em um tubo teste com meio de cultura contendo uma suspensão de cada microrganismo e incubado. Posteriormente, os CP foram lavados e transferidos para outros tubos contendo $50 \mathrm{~mL}$ de água por 5 minutos, em $0,2 \%$ de ácido peracético por 5 min ou em glutaraldeído por 30 minutos, plaqueados em ágar de cultura e incubados. O crescimento microbiano foi determinado por contagem de colônias após o plaqueamento.

Resultado: $O$ crescimento de Candida albicans foi inibido nos tratamentos com ácido peracético e glutaraldeído. O número de colônias nas resinas tratadas com solução salina foi superior a $10^{5} \mathrm{UFC} / \mathrm{mL}$. Nas resinas infectadas com E. coli, S. aureus e P. aeruginosa, o crescimento das colônias não foi inibido nas resinas tratadas com salina e ácido peracético, mas foi totalmente inibida pelo glutaraldeído.

Conclusão: A desinfecção com ácido peracético inibiu efetivamente o crescimento de C. albicans em todas as resinas acrílicas.

Palavras-chave: Ácido peracético; resinas acrílicas; Candida albicans

\author{
Cheila Denise Ottonelli Stopiglia a \\ Mariana Carissimi b \\ Maria Lúcia Scroferneker c \\ Carmen Beatriz Borges Fortes d
}

\begin{abstract}
- Graduate Programme in Medical Sciences, Universidade Federal do Rio Grande do Sul, Porto Alegre, RS, Brazil

b Municipal Department of Environmental Protection, City Hall of Caxias do Sul, Caxias do Sul, RS, Brazil

c Department of Microbiology, Institute of Basic Health Sciences, Universidade Federal do Rio Grande do Sul, Porto Alegre, RS, Brazil

d Department of Conservative Dentistry, School of Dentistry, Universidade Federal do Rio Grande do Sul, Porto Alegre, RS, Brazil
\end{abstract}

\author{
Correspondence: \\ Carmen Beatriz Borges Fortes \\ Faculdade de Odontologia \\ Universidade Federal do Rio Grande do Sul \\ Rua Ramiro Barcelos, 2492 \\ Porto Alegre, RS - Brasi \\ 90035-003 \\ E-mail:cbbfortes@yahoo.com.br
}

Received: April 27, 2011

Accepted: August 28, 2011

Conflict of Interest Statement: The authors state that there are no financial and personal conflicts of interest that could have inappropriately influenced their work.

Copyright: (C) 2011 Stopiglia et al.; licensee EDIPUCRS. This is an Open Access article distributed under the terms of the Creative Commons AttributionNoncommercial-No Derivative Works 3.0 Unported License. 


\section{Introduction}

Peracetic acid (PAA) is a chemical agent that originates from the mixture of hydrogen peroxide and acetic acid. The decomposition of a solution containing PAA has water, acetic acid and oxygen as by-products, all of which are biodegradable and atoxic. The PAA solution can be used as high-level disinfectant, and its action is similar to that of hydrogen peroxide, i.e., it promotes protein denaturation, impairment of cell wall permeability, oxidation of sulphydryl groups and of sulphur bonds in proteins, enzymes and other metabolites (1).

PAA is characterised by a very rapid action and broadspectrum antimicrobial activity, which inactivates Grampositive and Gram-negative bacteria, as well as fungi (2). PAA has been used since 1955 as a disinfectant or sterilant, mainly in the food industry and in suture threads. It has also been employed for the disinfection of plastic insulators and medical and dental equipment (3). Acrylic resins are polymers (plastics) used for the manufacture of prostheses, dental braces and intraocclusal devices. Acrylic resins are thermosensitive materials, and as they cannot be submitted to high-temperature disinfection techniques, the use of chemical disinfectants is necessary (4).

Acrylic resin items are considered semi-critical articles because they get in contact with the patient's healthy mucosa and must be submitted to high-level disinfection or sterilisation. The $1 \%$ sodium hypochlorite and $2 \%$ glutaraldehyde have been widely recommended for disinfection of acrylic resin items; however, these chemical agents are not ideal: $1 \%$ sodium hypochlorite is a bleaching agent and may interfere with the aesthetics of the prostheses whereas $2 \%$ glutaraldehyde releases toxic vapours, irritants and allergens, which cause eye, nose, and throat irritation, allergy, contact dermatitis, asthma and rhinitis (1,5-6).

The use of devices made of acrylic resins favours the growth of microorganisms, and is associated with diseases such as angular cheilitis, median rhomboid glossitis and denture-induced stomatitis. This infection has a multifactorial aetiology and can be caused by denture trauma, poor oral health, poor denture hygiene, continuous denture wearing, Candida albicans infection, and hypersensitiveness to denture materials. Thus, every intraoral device should be disinfected before placement in the patient's mouth. As PAA is biodegradable and does not produce toxic compounds, it seems to be ideal for the disinfection of acrylic resins (7).

Candida albicans is a commensal yeast that colonises the oral cavity and that is found in 30 to $70 \%$ of apparently healthy individuals. C. albicans is most commonly found in the oral cavity, either as a commensal organism or as a pathogen (8). C. albicans can adhere to and colonise the surface of acrylic resin in prostheses and develop biofilm, both in healthy patients and in those with pathological findings. Therefore, the prosthesis acts as a reservoir for fungi, re-infecting the oral mucosa after antifungal treatment in denture wearers with denture stomatitis (9).
The aim of this study was to assess the efficacy of peracetic acid for disinfection of dental acrylic resins experimentally contaminated with Candida albicans, Escherichia coli, Staphylococcus aureus and Pseudomonas aeruginosa.

\section{Methods}

The study was approved by the Research Ethics Committee of the School of Dentistry, affiliated with the Universidade Federal do Rio Grande do Sul, Porto Alegre, Brazil.

\section{Sampling}

The materials consisted of three types of colourless acrylic resins - thermosetting (VIPI CRIL ${ }^{\circledR}$ ), microwavecuring (VIPI WAVE ${ }^{\circledR}$ ) and self-curing (VIPI FLASH ${ }^{\circledR}$ ), all from Dental VIPI Ltda, São Paulo, Brazil. Fifteen materials measuring $30.0 \times 10.0 \times 3.2 \mathrm{~mm}( \pm 0.05 \mathrm{~mm})$ were prepared for each type of resin. The resins were proportioned, handled and polymerised according to the manufacturer's instructions. The materials were polished with 400-600 grit wet sandpaper and mechanically polished with pumice stone and calcium carbonate. We chose colourless resins because the visual inspection of their surface is easier.

\section{Microorganisms}

The strains used in the experiment were Candida albicans ATCC 10231, Escherichia coli ATCC 11/05, Staphylococcus aureus ATCC 25923 and Pseudomonas aeruginosa ATCC 15422. The inocula were prepared in saline solution and were standardized in a spectrophotometer at $530 \mathrm{~nm}$, with absorbance of $0.08-0.1$, and later diluted until obtaining $10^{4} \mathrm{CFU} / \mathrm{mL}$.

\section{Microbiological test}

For contamination, the materials were placed in a test tube containing $10 \mathrm{~mL}$ of brain heart infusion (BHI) broth (Oxoid, Cambridge, UK) with a final concentration of $10^{3} \mathrm{CFU} / \mathrm{mL}$ of each microorganism, and then incubated at $37^{\circ} \mathrm{C}$ for $24 \mathrm{~h}$. Negative control was obtained by the immersion of the materials in uncontaminated broth. Prior to the treatment, microbial growth was confirmed by the turbidity of the growth medium. All materials were removed from the broth using a pair of sterile tweezers and immersed in sterile $0.89 \%$ saline solution for $5 \mathrm{~min}$. The microbiological test was carried out in three groups, with five materials for each type of resin: control group, with immersion of materials in $50 \mathrm{~mL}$ of deionised water for $5 \mathrm{~min}$, PAA group, with immersion of materials in $50 \mathrm{~mL}$ of deionised water plus $0.2 \%$ PAA for $5 \mathrm{~min}$, and positive control, with immersion of materials in $50 \mathrm{~mL}$ of deionised water plus glutaraldehyde (Glutaron II, Indústria Farmacêutica Rioquímica Ltda, São José do Rio Preto, SP, Brazil) at the concentration of $2 \%$ for $30 \mathrm{~min}$. After that, the resins were washed in $0.89 \%$ saline solution for $5 \mathrm{~min}$ for removal of disinfectants, immersed in $10 \mathrm{~mL}$ of brain heart infusion (BHI) broth, and incubated at $37^{\circ} \mathrm{C}$ for $24 \mathrm{~h}$. Thereafter, the culture media were plated 
in BHI agar, incubated at $37^{\circ} \mathrm{C}$ for $24 \mathrm{~h}$, and the number of colonies was counted.

\section{Results}

The microbiological test showed that contamination by C. albicans, E. coli, $S$. aureus and P. aeruginosa occurred in all materials, regardless of the type of acrylic resin.

The microbiological test revealed that all materials were contaminated by the microorganisms because the culture medium was turbid after incubation. Growth after treatment with disinfectants was confirmed by the presence of colonies on the culture medium.

Candida growth was inhibited by peracetic acid and glutaraldehyde treatments. The number of colonies on resins treated with saline was greater than $10^{5} \mathrm{CFU} / \mathrm{mL}$.

In resins infected with $E$. coli, S. aureus and P. aeruginosa there was colony growth in those resins treated with saline and peracetic acid (count greater than $10^{5} \mathrm{CFU} / \mathrm{mL}$ ), but their growth was totally inhibited by glutaraldehyde.

\section{Discussion}

The results of this study demonstrate that immersion in $0.2 \%$ PAA for 5 min was effective for the disinfection of the three types of acrylic resins contaminated with C. albicans, thus corroborating the results of another study, which confirmed the efficacy of immersion in $0.2 \%$ PAA for $5 \mathrm{~min}$ for the sterilisation of the same types of resins, contaminated with Bacillus subtilis and Bacillus stearothermophilus (10). However, the same treatment was not efficient for the inhibition of E. coli, S. aureus and P. aeruginosa cells.

In order to prevent the cross-contamination of laboratory technicians and dental surgeons, $1 \%$ sodium hypochlorite and $2 \%$ glutaraldehyde are recommended for the disinfection of dental impression materials and dentures before any handling is done (11). However, glutaraldehyde has toxic effects on the skin and mucous membranes (12), whereas regular use of sodium hypochlorite causes bleaching of the denture material overtime, so its use is often disapproved by the patients (2). Therefore, PAA, which was effective for the disinfection of endoscopes (13), may be a suitable alternative substance to disinfect acrylic resins for dental treatment purposes.

Some limitations of the present study are intrinsically related to the type of laboratorial design, which do not reproduce all the complex conditions found in the oral cavity of denture patients with or without denture stomatitis. Therefore, the direct extrapolation of results for the dental clinics is not possible, and the present findings should be considered as an in vitro testing of the efficacy of disinfection substances against specific microorganisms.

\section{Conclusions}

In summary, the immersion in $0.2 \%$ PAA for 5 min inhibits the growth of $C$. albicans on the surface of all materials of acrylic resins analysed. Nevertheless, it is necessary to assess the influence of this method of disinfection on the physical and mechanical properties of these resins before establishing a disinfection protocol in the daily clinics.

\section{Acknowledgments}

The authors also express their special thanks to Capes (Coordenação de Aperfeiçoamento de Pessoal de Nível Superior) and CNPq (Conselho Nacional de Desenvolvimento Científico e Tecnológico) for their financial support to this study.

References 1. Rutala WA, Webber DJ. Disinfection of endoscopes: review of new chemical sterilants used for high-level disinfection. Infect Control Hosp Epidemiol 1999;20:69-76.

2. Rutala WA, Gergen MF, Webber DJ. Comparative evaluation of the sporicidal activity of new low-temperature sterilization technologies: ethylene oxide, plasma sterilization systems and liquid peracetic acid. Am J Infect Control 1998;26:393-8.

3. Rutala WA. Clinical effectiveness of low-temperature sterilization technologies. Infect Control Epidemiol 1998;19:798-804.

4. Council on Dental Materials and Devices and Council on Dental Therapeutics. Infection control in the dental office. J Am Dent Assoc 1978;97:673-7.

5. Rohrer MD, Bulard RA. Microwave sterilization. J Am Dent Assoc 1985; 1 10:194-8.

6. Stanley PM. Efficacy of peroxygen compounds against glutaraldehyde-resistant mycobacteria. Am J Infect Control 1999;27:339-43.

7. Hehn L. Avaliação da sorção, solubilidade e microdureza de resinas acrílicas após desinfecção com ácido peracético [Master's thesis]. Porto Alegre: Universidade Federal do Rio Grande do Sul. 2001.

8. Darwazeh AM, Al-Refai S, Al-Mojailwel S. Isolation Candida species from the oral cavity and fingers of complete denture wearers. J Prosthetic Dent $2001 ; 86: 420-3$.

9. Chandra J, Mukheriee PK, Leidich SD, Faddoul FF, Hoyer LL, Douglas LJ, Ghannoum MA. Antifungal resistance of candidal biofilms formed on denture acrylic in vitro. J Dent Res $2001 ; 80: 903-8$. 
10. Chassot ALC, Poisl MI, Samuel SMW. In vitro and in vivo evaluation of the efficacy of peracetic acid based disinfectant for decontamination of acrylic resins. Braz Dent J 2006;1 7:1 17-21.

11. McNeill MR, Couter WA, Hussey DL. Disinfection of irreversible hydrocolloid impressions: a comparative study. Int J Prosthodont 1992;5:563-7.

12. Polyzois GL, Zissis AJ, Yannikakis SA. The effect of glutaraldehyde and microwave disinfection on some properties of acrylic denture resin. Int J Prosthodont 1995;8:150-4.

13. BSG Endoscopy Committee. Cleaning and disinfection of equipment for gastrointestinal endoscopy. Report of a working party of the British Society of Gastroenterology Endoscopy Committee. Gut 1998;42:585-93. 